\title{
ANALISIS YURIDIS TERHADAP KEBIJAKAN PEMERINTAH MENGENAI PENANGANAN PANDEMI VIRUS CORONA DISEASE 2019 (COVID-19) DI INDONESIA
}

\author{
Dr. Anwar Hidayat, S.H., M.H. Email: Anwar.hidayat@ubpkarawang.ac.id \\ Budiman, S.H. Email: budiman@mhs.ubpkarawang.ac.id
}

Fakultas Hukum Universitas Buana Perjuangan Karawang

\begin{abstract}
ABSTRAK
Perkembangan pandemi Covid-19 saat ini sangat mengkhawatirkan dimana terjadinya suatu peningkatan kasus corona khusus di Indonesia. Penelitian ini bertujuan untuk mengetahui dan menganalisis kebijakan yang diambil pemerintah dalam penanganan pandemi Covid-19 serta langkah-langkah yang diambil pemerintah untuk menganggulangi dampak-dampak, terutama dampak dari segi ekonomi dan sosial akibat pandemi Covid-19. Metode penelitian hukum yang digunakan yakni metode penelitian hukum normatif. Adapun pendekatan yang digunakan dalam penelitian ini adalah pendekatan perundang-undangan dan pendekatan konseptual. Penelitian ini berlandaskan pengaturan perundang-undangan yang mengatur mengenai penanganan dan penganggulangan pandemi Covid-19 serta analisis atas konsep penetapan peraturan perundang-undangan tersebut. Hasil dari penelitian ini adalah dalam rangka penanganan Covid-19, berawal dari pemerintah tmengeluarkan kebijakan tentang Pembatasan Sosial Berskala Besar yang merujuk pada Undang-Undang Nomor 6 Tahun 2018 tentang Kekarantinaan Kesehatan. Peraturan pelaksanaannya yaitu Peraturan Pemerintah Nomor 21 Tahun 2020 tentang Pembatasan Sosial Berskala Besar, serta Keputusan Presiden tentang Kedaruratan Kesehatan sampai dengan saat ini pemerintah telah mengeluarkan kebijakan PPKM yang dimana dilakukan secara berkala. Untuk menganggulangi dampak Covid-19 dari segi ekonomi dan sosial pemerintah mengambil beberapa kebijakan-kebijakan, yang diantaranya adalah: Peraturan Menteri Keuangan Republik Indonesia Nomor 23/Pmk.03/2020 tentang Insentif Pajak Untuk Wajib PajakTerdampak Wabah Virus Corona; Peraturan Otoritas Jasa Keuangan Republik
\end{abstract}

\section{Kata Kunci : Kebijakan, Penanganan, Covid-19}




\section{ABSTRACT}

The current development of the Covid-19 pandemic is very worrying where there is an increase in special corona cases in Indonesia. This study aims to identify and analyze the policies taken by the government in handling the Covid-19 pandemic and the steps taken by the government to mitigate the impacts, especially the economic and social impacts of the Covid-19 pandemic. The legal research method used is the normative legal research method. The approach used in this research is a statutory approach and a conceptual approach. This research is based on the legislation governing the handling and handling of the Covid-19 pandemic as well as an analysis of the concept of establishing these laws and regulations. The results of this study are in the context of handling Covid-19, starting with the government issuing a policy on Large-Scale Social Restrictions which refers to Law Number 6 of 2018 concerning Health Quarantine. The implementing regulations are Government Regulation Number 21 of 2020 concerning Large-Scale Social Restrictions, as well as the Presidential Decree on Health Emergencies. Until now, the government has issued a PPKM policy which is carried out regularly. To address the economic and social impact of Covid19, the government has taken several policies, including: Regulation of the Minister of Finance of the Republic of Indonesia Number 23/Pmk.03/2020 concerning Tax Incentives for Taxpayers Affected by the Corona Virus Outbreak; Regulation of the Financial Services Authority of the Republic of Indonesia Number 11 /Pojk.03/2020 concerning National Economic Stimulus as a Countercyclical Policy for the Impact of the Spread of Corona Virus Disease2019; and Instruction of the President of the Republic of Indonesia Number 4 of 2020 concerning Refocussing of Activities, Reallocation of Budgets, and Procurement of Goods and Services in the Context of Accelerating Handling of Corona Virus Disease 2019 (Covid-19).

\section{Keyword : Policy, Handling, Covid-19}




\section{PENDAHULUAN}

Pemerintah sangat berperan besar dalam mencapai tujuan negara, dimana di masa kini kebanyakan negara menganut paham negara kesejahteraan (welfare state). Berdasarkan konstitusi yaitu UUD NRI Tahun 1945 Indonesia memenuhi ciri-ciri negara kesejahteraan tersebut, terutama berdasarkan Alinea Keempat Pembukaan UUD NRI Tahun 1945 yang kemudian dijawantahkan ke dalam Batang Tubuh yaitu pasal-pasalnya.

Paham negara kesejahteraan jelas tersurat dalam UUD NRI Tahun 1945 karena mengatur beberapa hal yaitu bahwa perekonomian yang berdasarkan asas kekeluargaan, negara menguasai bumi, air, kekayaan alam serta cabang produksi yang penting untuk kemakmuran rakyat, pembiayaan Pendidikan dasar, pengembangan sistem jaminan sosial nasional, pemberdayaan masyarakat serta penyediaan fasilitas pelayanan kesehatan dan fasilitas pelayanan publik. Untuk mewujudkan tujuan dari negara kesejahteraan, tugas eksekutif sebagai pelaksana sangat penting karena makin luasnya lingkup kesejahteraan masyarakat berdasarkan perkembangan jaman.

Tugas eksekutif dalam pemerintahan untuk mewujudkan kesejahteraan rakyat tersebut oleh Lemaire disebut sebagai bestuurzorg yaitu penyelenggaraan kesejahteraan umum oleh pemerintah. ${ }^{1}$ Karena sangat luasnya lingkup bestuurzorg tersebut maka tidakmungkin eksekutif hanya menggunakankewenangan yang bersifat terikat (gebondenbevoegheid) yang diatur dalam peraturan perundang-undangan.

Karena peraturan perundangundangan tertulis tentunya tidak dapat mengatur segala hal dengan lengkap dan tidak selalu sesuai dengan keadaan terkini (up to date) maka pemerintah juga dapat menggunakan "kebijaksanaan bebas", yaitu wewenang untuk mengambil tindakan atas inisiatif sendiri guna menyelesaikan suatu masalah genting atau mendesak dan belum ada ketentuannya dalam peraturan yang dikeluarkan oleh kekuasaan legislative yang dikenal dengan freies ermessen.

Norma itu akan menjadi hukum yang berlaku apabila dikehendaki oleh masyarakat, tertulis, dikeluarkan oleh negara

1 Utrecht E. (1957). Pengantar Hukum Tata UsahaNegara Indonesia. Jakarta: NV Balai Buku Indonesia,h. 22-23 
ANALISIS YURIDIS TERHADAP KEBIJAKAN PEMERINTAH MENGENAI PENANGANAN PANDEMI VIRUS CORONA DISEASE 2019 (COVID-19) DI INDONESIA: Anwar H.., Budiman

dan memuat perintah, yang menjelaskan bahwa hukum ditaati bukan karena dinilai adil atau baik, namun karena hukum itu tertulis dan disahkan oleh penguasa. ${ }^{2}$ Penggunaan wewenang tersebut diperlukan terutama setelah berkembangnya wabah corona virus disease 2019 (Covid-19) yang kemudiah menjadi epidemi dan sekarang menjadi pandemi yang berskala global. Pemerintah Pusat telah mengeluarkan berbagai peraturan perundang-undangan terkait Pandemi Covid-19.

Pelaksanaan wewenang pemerintah dalam bentuk kebijakan-kebijakan tersebut tentunya juga harus disertai pertimbangan mengenai langkah dan akibat yang mungkin timbul. Diharapkan kebijakan yang diambil dapat dilaksanakan dengan langkah-langkah yang terukur dan dengan akibat yang dikehendaki yaitu mencegah penyebaran Covid-19 di Indonesia. Virus corona memiliki gejala yang sama mirip flu dan berkembang cepat hingga mengakibatkan infeksi lebih parah dan gagal organ. Kelelawar, ular, dan berbagai hewan eksotis lain hingga kini masih dianggap sebagai vektor virus Corona atau Covid-19.
Terlepas dari benar tidaknya informasi tersebut, Covid-19 membuktikan diri mampu menular antar manusia. Penularan sangat cepat hingga Organisasi Kesehatan Dunia WHO menetapkan pandemi virus Corona atau Covid-19. Pandemi atau epidemi global mengindikasikan infeksi Covid-19 yang sangat cepat hingga hampir tak ada negara atau wilayah di dunia yang terhindar darivirus Corona. Peningkatan jumlah kasus terjadi dalam waktu singkat hingga butuh penanganan secepatnya karena belum ada obat spesifik untuk menangani kasus infeksi virus Corona atau Covid-19. Dengan demikian, Pemerintah mengeluarkan kebijakan untuk menangani corona virus disease 2019 (Covid-19) di Indonesia.

\section{PERMASALAHAN}

1. Bagaimana kebijakan pemerintah dalam penanganan pandemi corona virus disease 2019 (Covid-19) di Indonesia?

2. Bagimana dampak dari adanya pandemi corona virus disease 2019 (Covid19) dan penanggulangannya di Indonesia?

\section{METODE PENELITIAN}

Metode penelitian hukum yang digunakan dalam penelitian ini yakni 
ANALISIS YURIDIS TERHADAP KEBIJAKAN PEMERINTAH MENGENAI PENANGANAN PANDEMI VIRUS CORONA DISEASE 2019 (COVID-19) DI INDONESIA: Anwar H.., Budiman

metode penelitian hukum normatif (normative legal research). Penelitian hukum normatif sendiri merupakan suatu metode penelitian yang meneliti hukum dari perspektif internal dengan objek penelitiannya adalah norma hukum. Adapun pendekatan yang digunakan dalam penelitian ini adalah pendekatan perundangundangan (statute approach) dan pendekatan konseptual (conceptual approach). Penelitian ini berlandaskan pengaturan perundang-undangan yang mengatur mengenai penanganan dan penganggulangan pandemi Covid-19 serta analisis atas konsep penetapan peraturan perundang-undangan tersebut. Dikarenakan penelitian ini merupakan penelitian hukum normatif, maka sumber bahan hukum yang digunakan adalah bahan hukum primer dan bahan hukum sekunder. Bahan hukum primer berupa asas dan norma hukum yang terdapat pada peraturan perundangundangan, dan bahan hukum sekunder berupa buku-buku danjurnal-jurnal hukum, kamus dan ensiklopedia hukum serta sumber dari internet yang berkaitan dengan topik pembahasan dalam penelitian ini.

\section{HASIL DAN PEMBAHASAN}

\section{A.Kebijakan Pemerintah Dalam Penanganan Pandemi Corona Virus Disease 2019 (Covid-19) di Indonesia}

Penyebaran Pandemi Covid-19 di mulai dari Wuhan China Desember 2019 dan sampai sekarang telah merambah 182 negaradari 194 negara, dalam perjalanan selama 4 bulan dan penyebarannya sangat dahsyat. Salah satu penyebab awal Covid-19 diperkirakan adalah transmisi atau penyebaran melalui kelelawar yang kemudian dikonsumsi oleh manusia. Penyebaran dibeberapa negara terindikasi positif, dapat disembuhkan, dan meninggal dunia. Penyebaran global dan data minggu kedua bulan April 2020, jumlah yang teridikasi positif dan meninggal di dunia, yaitu1.853.155 orang, sembuh 423.625 orang, dan meninggal 114.246 orang. Sedangkan data saat ini di tahun 2021 mencapai 223 Negara yang terkonfirmasi ada sekitar 198.234.951, yang meninggal dunia 4.227.359. ${ }^{3}$ Sedangkan di Indonesia data pertanggal 02/08/2021 yang positif 3.462.800, sembuh 2.842.345, dan meninggal dunia 97.291. Akibat luas dan masifnya penyebaran Covid-19 di Indonesia maka pemerintah harus mengambil kebijakan untuk menanggulanginya.

\footnotetext{
${ }^{3}$ Sumber WHO tanggal 02-08-2021
} 
ANALISIS YURIDIS TERHADAP KEBIJAKAN PEMERINTAH MENGENAI PENANGANAN PANDEMI VIRUS CORONA DISEASE 2019 (COVID-19) DI INDONESIA: Anwar H.., Budiman

Penetapan kebijakan merupakan suatu faktor penting bagi negara untuk mencapai tujuannya. Kebijakan ini kemudian diikuti dan dilaksanakan oleh para pelaku (stakeholders) dalam rangka memecahkan suatu permasalahan tertentu.

Selanjutnya dinyatakan Indonesia dalam status bencana nasional non alam akibat Covid-19.8 Kebijakan tentang penanggulangan Covid-19 di Indonesia, menggunakan PSBB (Pembatasan Sosial Bersekala Besar), yang di mulai dari berberapa daerah, seperti Provinsi DKI, telah dimulai dari tanggal 10 April 2020 samapai dengan 23 April 2020, dan kemudian diikuti oleh Provinsi dan $\mathrm{k}$ abupaten/kota yang lain, seperti Provinsi Banten di Kabupaten Tangerang, dan Kota Tangerang. Di Provinsi Jawa Barat, dimulai dari Kabupaten Bogor, Kota Bogor, Kota Bekasi, dan Kota Depok.

Kebijakan pemerintah tentang PSBB adalah kebijakan yang Intra-Legal berdasarkan pada peraturan perundangundangan dan asas-asas hukum, dan juga kebebasan mempertimbangkan Ekstra-Legal, karena banyak hal yang belum diatur dalam peraturan perundangan, tetapi Covid-19 suatu Pandemi yang menyebar begitu cepat dalam jangka dua bulan telah merambah 162 negara dari 194 negara, episentrum dari
China, ke Italia, dan sekarang Amerika Serikat, tidak mudah memprediksi penyebaran dan tiba-tiba sudah menjadi besar, seperti apa yang terjadi di negara adidaya Amerika Serikat, kewalahan menghadapi pandemi Virus Covid-19. Begitu besarnya kemampuan virus ini dalam menginfeksi dan menyebar dibuktikan dengan catatan bahwa sampai sejauh ini masih banyak orang yang terinfeksi Covid19 dengan jumlah yang makin bertambah. Kebijakan PSBB sendiri merunjuk pada Undang-Undang Nomor 6 Tahun 2018 tentang Kekarantinaan Kesehatan. Untuk mendukung pemberlakuannya, pemerintah merilis dua regulasi turunan, yaitu Peraturan Pemerintah Nomor 21 Tahun 2020 tentang Pembatasan Sosial Berskala Besar serta Keputusan Presiden tentang Kedaruratan Kesehatan. Dengan regulasi yang ada, Presiden meminta kepala daerah tidak membuat kebijakan sendiri dan tetap terkoordinasi dengan pemerintah pusat lewat Ketua Gugus Tugas. PSBB dapat diusulkan oleh gubernur/wali kota kepada Menteri Kesehatan dengan pertimbangan Ketua Gugus Tugas, atau dapat diusulkan oleh Ketua Gugus Tugas kepada Menteri Kesehatan. Saat bersamaan, masyarakat juga diminta tetap menjaga jarak aman untuk memutus rantai penularan virus. Menjaga 
ANALISIS YURIDIS TERHADAP KEBIJAKAN PEMERINTAH MENGENAI PENANGANAN PANDEMI VIRUS CORONA DISEASE 2019 (COVID-19) DI INDONESIA: Anwar H.., Budiman

jarak aman antar orang (social distancing) dan membatasi seluruh akses masuk maupun keluar dan dari suatu wilayah dinilai efektif untuk mengendalikan persebaran Covid-19. Pemerintah telah menerapkan kebijakan PSBB untuk mencegah semakin meluasnya penularan Covid-19. Detail teknis dan syarat-syarat mengenai PSBB dituangkan dalam Peraturan Menteri Kesehatan RI Nomor 9 Tahun 2020 tentang Pedoman Pembatasan Sosial Berskala Besar Dalam Rangka Percepatan Penanganan CoronaVirus Disease 2019 (Covid-19) yang ditandatangani oleh Menteri Kesehatan RI. PSBB adalah pembatasan kegiatan tertentu penduduk dalam suatu wilayah yang diduga terinfeksi corona virus disease 2019 (Covid19) sedemikian rupa untuk mencegah kemungkinan penyebarannya. ${ }^{4}$ Agar bisa menetapkan PSBB, setiap wilayah harus memenuhi kriteria. Jumlah kasus dan atau jumlah kematian akibat penyakit meningkat dan menyebar secara signifikan dan cepat kebeberapa wilayah.

Terdapat kaitan epidemiologis dengan kejadian serupa diwilayah atau negara lain. Apabila PSBB dilaksanakan di suatu wilayah maka pelaksanaan PSBB meliputi beberapa hal yakni peliburan tempat sekolah dan tempatkerja, pembatasan kegiatan keagamaan,pembatasan kegiatan di fasilitas umum. Namun, peliburan dan pembatasan tersebut dikecualikan untuk pelayanan tertentu seperti pelayanan kebutuhan bahan pangan, pelayanan kesehatan dan keuangan .

Pembatasan juga dikecualikan untuk pelayanan kesehatan, pasar, toko, supermarket dan fasilitas kesehatan. PSBB dilaksanakan selama masa inkubasi terpanjang Virus Covid-19 atau selama 14 hari dan dapat diperpanjang jika masih terdapat bukti penyebaran. Pandemi Covid19 dapat dikategorikan sebagai kedaruratan kesehatan masyarakat adalah kejadian kesehatan masyarakat yang bersifat luar biasa dengan ditandai penyebaran penyakit menular dan/atau kejadian yang disebabkan oleh radiasi nuklir, pencemaran biologi, kontaminasi kimia, bioterorisme, dan pangan yang menimbulkan bahaya kesehatan dan berpotensi menyebar lintas wilayah atau lintas negara. Penanganan kedarurat kesehatan tersebut didasarkan atas Undang-Undang Nomor 6 Tahun 2018 Tentang Kekarantinaan Kesehatan (UU

\footnotetext{
4 Peraturan Menteri Kesehatan RI Nomor 9 Tahun 2020 tentang Pedoman Pembatasan Sosial Berskala Besar
} 
ANALISIS YURIDIS TERHADAP KEBIJAKAN PEMERINTAH MENGENAI PENANGANAN PANDEMI VIRUS CORONA DISEASE 2019 (COVID-19) DI INDONESIA: Anwar H.., Budiman

Kekarantinaan $\quad$ Kesehatan). ${ }^{5}$ UU Karantina Rumah, Karantina Wilayah,

Kekarantinaan Kesehatan dengan jelas menerangkan tentang adanya pembatasan masuk-keluarnya individu ke daerah yang telah dinyatakan sumber wabah, termasuk mengatur pula tentang adanya perintah untuk melakukan isolasi karantina wilayah, vaksinasi dan lain sebagainya untuk menghentikan penyebaran wabah yang terjadi di Indonesia. UU Kekarantinaan Kesehatan, menetukan bahwa terdapat beberapa jenis karantinakesehatan yaitu Karantina Rumah, Karantina Rumah Sakit, Karantina Wilayah dan Pembatasan Sosial Berskala Besar. Karantina wilayah juga dilakukan dibeberapa negara yang terdampak sangat berat terhadap pandemi Covid-19.

Beberapa negara di Eropa dan China menerapkan karantina wilayah. Karantina wilayah tersebut melarang warga masuk atau keluar dari daerah yang terdampak Covid-19. Didalam karantina wilayah itu juga ditekankan adanya"social / individuals distancing" dengan kebijakan melarang seluruh kegiatanyang mengumpulkan massa. Jika terjadi situasi kedaruratan Kesehatan masyarakat seperti pandemi Covid-19 ini maka di wilayah terdampak dapat dilakukan

5 Undang-Undang Nomor 6 Tahun 2018 Tentang Kekarantinaan Kesehatan
Karantina Rumah Sakit, atau Pembatasan Sosial Berskala Besar oleh Pejabat Karantina Kesehatan. Pelaksanaan Karantina Rumah, Karantina Wilayah, Karantina Rumah Sakit, atau Pembatasan Sosial Berskala Besar tersebut harus didasarkan pada pertimbangan epidemiologis, besarnya ancaman, efektifitas, dukungan sumber daya, teknis operasional, pertimbangan ekonomi, sosial, budaya, dan keamanan.11 Namun khusus mengenai karantina wilayah dan pembatasan sosial berskala besar penentuan harus ditetapkan oleh menteri.12 Berdasarkan data terkini Covid-19 yang berjumlah 6.248 kasus13, maka hal ini telah masuk kriteria kejadian Kesehatan masyarakat yang bersifat luar biasa karena ditandai penyebaran penyakit menular yang menimbulkan bahaya kesehatan dan berpotensi menyebar lintas wilayah ataulintas negara berdasarkan UU Kekarantinaan Kesehatan.

Penetapan karantina wilayah sesuai dengan undang-undang sangat dibutuhkan. Karena hal tersebut sangat berkaitan dengan kedudukan Indonesia sebagai negara dengan ciri negara kesejahteraan/welfarestaat, yang harus turutaktif dalam menyelenggarakan kesejahteraan masyarakat termasuk dalam bidang kesehatan. Khusus mengenai 
ANALISIS YURIDIS TERHADAP KEBIJAKAN PEMERINTAH MENGENAI PENANGANAN PANDEMI VIRUS CORONA DISEASE 2019 (COVID-19) DI INDONESIA: Anwar H.., Budiman

kewenangan dibidang kesehatan

berdasarkan Undang-Undang Nomor 23

Tahun 2014 tentang Pemerintahan Daerah sebagaimana dirubah terakhir dengan Undang-Undang Nomor 9 Tahun 2015 Tentang Perubahan Kedua Atas UndangUndang Nomor 23 Tahun 2014 tentang Pemerintahan Daerah (UU Pemda) kesehatan merupakan urusan pemerintahan konkuren yang menjadi kewenangan Daerah sehingga Pemerintah Daerah berwenang mengambil kebijakan di bidang kesehatan dalam hal tertentu jika tidak diatur berbeda oleh peraturan perundang-undangan lain. ${ }^{6}$ Sebagai tindak lanjut atas pandemi Covid-19 pemerintah kemudian mengambilkebijakan untuk melaksanakan PSBB.

Untuk mendukung pemberlakuannya, pemerintah merilis beberapa regulasi turunan, yaitu Peraturan Pemerintah Nomor 21 Tahun 2020 tentang Pembatasan Sosial Berskala Besar Dalam Rangka Percepatan Penanganan Corona Virus Disease 2019 (Covid-19) ${ }^{7}$ kemudian Keputusan Presiden Nomor 11 Tahun 2020 tentang Penetapan

6 Undang-Undang Nomor 9 Tahun 2015 Tentang Perubahan Kedua Atas UndangUndang Nomor 23 Tahun 2014 tentang Pemerintahan Daerah

7 Peraturan Pemerintah Nomor 21 Tahun 2020 tentang Pembatasan Sosial Berskala Besar Dalam Rangka Percepatan Penanganan Corona Virus Disease 2019 (Covid-19)
Kedaruratan Kesehatan Masyarakat Corona Virus Disease 2019 (Covid-19) ${ }^{8}$ serta Peraturan Menteri Kesehatan Republik Indonesia Nomor 9 Tahun 2020 tentang Pedoman Pembatasan. ${ }^{9}$ Sosial Berskala Besar Dalam Rangka Percepatan Penanganan Corona Virus Disease 2019 (Covid-19).

Dengan regulasi-regulasi tersebut, Presiden meminta kepala daerah tidak membuat kebijakan sendiri dan tetap terkoordinasi dengan pemerintah pusat lewat Ketua Gugus Tugas. PSBB dapat diusulkan oleh gubernur/wali kota kepada Menteri Kesehatan dengan pertimbangan Ketua Gugus Tugas, atau dapat diusulkan oleh Ketua Gugus Tugas kepada Menteri Kesehatan.

\section{B. Dampak dari Adanya Pandemi Corona Virus Disease 2019 (Covid-19) dan Penanggulangannya di Indonesia}

Akibat dari Covid-19 ini tidak hanya dibidang kesehatan, namun juga di berbagai bidang terutama di bidang ekonomi. Akibat dari Covid-19 tersebut diperparah dengan

\footnotetext{
${ }^{8}$ Keputusan Presiden Nomor 11 Tahun 2020 tentang Penetapan Kedaruratan Kesehatan Masyarakat Corona Virus Disease 2019 (Covid19)

9 Peraturan Menteri Kesehatan Republik Indonesia Nomor 9 Tahun 2020 tentang Pedoman Pembatasan
} 
ANALISIS YURIDIS TERHADAP KEBIJAKAN PEMERINTAH MENGENAI PENANGANAN PANDEMI VIRUS CORONA DISEASE 2019 (COVID-19) DI INDONESIA: Anwar H.., Budiman

kebijakan-kebijakan yang mau tidak mau harus diambil oleh pemerintah. Sebab dengan pelaksanaan physical distancing, kemudian social distancing dan terakhir dibeberapa daerah ditetapkan adanya PSBB lalu saat ini diberlakukaan kebijakan PPKM maka kegiatan perokonomian menjadi sangat terdampak.

Penanggulangan dampak dari kebijakan ini harus dilakukan pemerintah sebagai perwujudan pemerintah yang antisipatif sebagai salah satu model pemerintahan. Untuk menanggulangi akibat dari kebijakan penanggulangan Covid-19, maka pemerintah kemudian mengambil beberapa kebijakan-kebijakan terutama dibidang ekonomi, yang diantaranya adalah:

1.Peraturan Menteri Keuangan Republik Indonesia Nomor 23/Pmk.03/2020 Tentang Insentif Pajak Untuk Wajib Pajak Terdampak Wabah Virus Corona;

\section{Peraturan Otoritas Jasa Keuangan}

Republik Indonesia Nomor 11/Pojk.03/2020

Tentang Stimulus Perekonomian Nasional Sebagai Kebijakan Counter cyclical Dampak Penyebaran Corona Virus Disease 2019;

3.Instruksi Presiden Republik Indonesia Nomor 4 Tahun 2020 Tentang Refocussing Kegiatan, Realokasi Anggaran, Serta
Pengadaan Barang Dan Jasa Dalam Rangka Percepatan Penanganan Corona Virus Disease 2019 (Covid-19);

Selain langkah-langkah melalui pengambilan kebijakan tersebut, pemerintah juga tentunya harus dibantu oleh sector swasta, terutama terkait penerapan relaksasi kredit/restrukturisasi kredit bagi sektorsektor yang terdampak wabah virus corona (Covid-19) yang diatur dalam POJK Nomor 11/POJK.03/2020 tentang Stimulus perekonomian sebagai kebijakan Countercyclical. Di samping langkahlangkah tersebut pemerintah sebenarnya telah melakukan upaya untuk meminimalisir dampak ekonomi, yaitu dengan tidak menerapkan karantina wilayah.

Beberapa dampak ekonomi yang dapat terjadi adalah banyak sektor-sektor baik perdagangan, informal maupun pariwisata yang merugi. Siklus perputaran uang kacau, dikarenakan banyakanya kerugian yang dialami pengusaha. Namun tidak dapat dipungkiri bahwa beberapa komoditi menjadi untung terutama mereka yang menyediakan alat-alat kesehatan ataupun segala sesuatu yang terkait dengan pemberantasan atau pencegahan Covid-19. Disamping itu, Pemerintah juga mengeluarkan beberapa kebijakan sebagai 
ANALISIS YURIDIS TERHADAP KEBIJAKAN PEMERINTAH MENGENAI PENANGANAN PANDEMI VIRUS CORONA DISEASE 2019 (COVID-19) DI INDONESIA: Anwar H.., Budiman

wujud bantuan kepada masyarakat sebagai berikut:

1.Keringanan biaya listrik Sebagai wujud bantuan kepada masyarakat, Pemerintah menggratiskan beban listrik bagi konsumen PLN dengan daya 450 VA selama 3 bulan ke depan, yakni untuk biaya April, Mei, dan Juni. Sementara pengguna yang berlangganan daya sebesar $900 \mathrm{kwh}$ subsidi akan menerima diskon atau potongan harga sebesar 50 persen untuk jangka waktu yang sama. Artinya hanya membayar separuh untuk bulan April, Mei, dan Juni 2020.

2.Keringanan kredit Sejumlah kalangan seperti pengemudi ojek online, nelayan, dan sopir taksi, dipastikanakan mendapat kelonggaran kredit kendaraan bermotor selama 1 tahun terhitung mulai 1April 2020. Pembayaran bunga atau angsuran diberikan kelonggaran selama 1 tahun. Tak hanya itu, Pemerintah juga akan memberikan keringanan bagi pengusaha sector kecil dan menengah yang melakukan kredit di bawah Rp. 10 miliar. Mereka akan diberi penundaan cicilan selama 1 tahun dan penurunan bunga.

3.Gelontorkan anggaran Rp. 405, 1 Triliun Untuk memenuhi sejumlah kebutuhan ditengah wabah Covid-19, Pemerintah Pusat gelontorkan anggaran sebanyak Rp.
405,1 triliun melalui Anggaran Pendapatan Belanja Negara (APBN) 2020. Kebijakan ini sudah ditetapkan melalui Peraturan Pemerintah Pengganti Undang-Undang (Perpu) tentang Stabilitas Perekonomian di masa Pandemi Covid-19. Anggaran bidang kesehatan akan diprioritaskan untuk perlindungan tenaga kesehatan terutama pembelian APD, pembelian alat-alat kesehatan seperti test kit, reagen, ventilator, dan lain-lain. Selain itu,upgrade rumah sakit rujukan termasuk wisma atlet, insentif dokter, perawat dantenaga rumah sakit serta santunan kematian tenaga medis serta penanganan permasalah kesehatan lainnya. Setidaknya Rp. 75 triliun akan diarahkan untuk belanja di sector kesehatan, Rp. 70,1 triliun untuk insentif perpajakan dan stimulus kredit usaha rakyat, dan Rp. 110 triliun akan dialokasikan untuk perlindungan sosial. Lainnya akan digunakan untuk pembiayaan program pemulihan ekonomi nasional dan cadangan.

\section{KESIMPULAN}

1.Dalam rangka penanganan pandemiCovid19, Pemerintahtelah mengeluarkan kebijakan tentang Pembatasan Sosial Berskala Besar (PSBB). Kebijakan PSBB sendiri merujuk pada Undang-Undang Nomor 6 Tahun 2018 tentang Kekarantinaan 
ANALISIS YURIDIS TERHADAP KEBIJAKAN PEMERINTAH MENGENAI PENANGANAN PANDEMI VIRUS CORONA DISEASE 2019 (COVID-19) DI INDONESIA: Anwar H.., Budiman

Kesehatan. Untuk mendukung b.Peraturan Otoritas Jasa Keuangan pemberlakuannya pemerintah merilis dua regulasi turunan, yaitu Peraturan Pemerintah tentang Pembatasan Sosial Berskala Besar (PP Nomor 21 Tahun 2020) serta Keputusan Presiden tentang Kedaruratan Kesehatan. Dengan regulasi yang ada, Presiden meminta kepala daerah tidak membuat kebijakan sendiri dan tetap terkoordinasi dengan pemerintah pusat lewat Ketua Gugus Tugas. PSBB dapat diusulkan oleh gubernur/wali kota kepada Menteri Kesehatan dengan pertimbangan Ketua Gugus Tugas, atau dapat diusulkan oleh Ketua Gugus Tugas kepada Menteri Kesehatan. Saat bersamaan, masyarakat juga diminta tetap menjaga jarak aman untuk memutus rantai penularan virus. Menjaga jarak aman antar orang (social distancing) dan membatasi seluruh akses masuk maupun keluar dan dari suatu wilayah dinilai efektif untuk mengendalikan persebaran Covid-19.

2.Untuk menganggulangi dampak dariCovid-19 pemerintah mengambil beberapa kebijakan-kebijakan terutama di bidang ekonomi, yang diantaranya adalah :

a.Peraturan Menteri Keuangan Republik Indonesia Nomor 23/Pmk.03/2020 Tentang Insentif Pajak Untuk Wajib Pajak Terdampak Wabah Virus Corona; Republik Indonesia Nomor 11/Pojk.03/2020 Tentang Stimulus Perekonomian Nasional Sebagai Kebijakan Counter cyclical Dampak Penyebaran Corona Virus Disease 2019

c.Instruksi Presiden Republik Indonesia Nomor 4 Tahun 2020 Tentang Refocussing Kegiatan,Realokasi Anggaran, serta Pengadaan Barang Dan Jasa Dalam Rangka Percepatan Penanganan Corona Virus Disease 2019 (Covid-19);

d.Kebijakan sebagai wujud bantuan kepada masyarakat seperti keringanan biaya listrik, keringanan kredit, dan menggelontorkan anggaran Rp. 405,1 triliun untuk memenuhi kebutuhan ditengah wabah Covid-19 melalui Anggaran Pendapatan Belanja Negara (APBN) 2020

\section{DAFTAR PUSTAKA}

\section{A. BUKU-BUKU}

Ramadhan, M. C. Pengaruh Aliran Positivisme Dalam Kebijakan Pembentukan Peraturan Perundang-undangan di Indonesia.Warta Dharmawangsa, 2017

Utrecht E. Pengantar Hukum Tata UsahaNegara Indonesia. Jakarta: NV Balai Buku Indonesia 1998,h. 22-23

Zahrotunnimah, Z. (2020). Langkah Taktis Pemerintah Daerah Dalam Pencegahan Penyebaran Virus Corona Covid-19 di 
ANALISIS YURIDIS TERHADAP KEBIJAKAN PEMERINTAH MENGENAI PENANGANAN PANDEMI VIRUS CORONA DISEASE 2019 (COVID-19) DI INDONESIA: Anwar H.., Budiman

Indonesia, SALAM: Jurnal Sosial dan Budaya Syar-i, 7(3), 247-160.

\section{B. PERATURAN PERUNDANG- UNDANGAN}

Undang-Undang Nomor 23 Tahun

2014 tentang Pemerintahan

Daerah.

Undang-Undang Nomor 6 Tahun

2018 tentang Kekarantinaan

Kesehatan.

Peraturan Pemerintah Nomor 21

Tahun 2020 tentang

Pembatasan Sosial

Berskala Besar Dalam

Rangka Percepatan

Penanganan Corona Virus

Disease 2019 (Covid-19).

Keputusan Presiden Nomor 11

Tahun $2020 \quad$ tentang

Penetapan Kedaruratan

Kesehatan Masyarakat

Corona Virus Disease 2019

(Covid-19).

Instruksi Presiden Republik

Indonesia Nomor 4 Tahun

2020 Tentang Refocussing

Kegiatan, Realokasi

Anggaran,Serta Pengadaan

Barang Dan Jasa Dalam

Rangka Percepatan
Penanganan Corona Virus

Disease 2019 (Covid-19).

Peraturan Menteri Keuangan Republik Indonesia Nomor 23/Pmk.03/2020

tentang Insentif Pajak Untuk Wajib Pajak Terdampak Wabah Virus Corona.

Peraturan Otoritas Jasa Keuangan Republik Indonesia Nomor 11 /Pojk.03/2020 tentang Stimulus Perekonomian Nasional Sebagai Kebijakan Countercyclical Dampak Penyebaran Corona Virus Disease 2019.

\section{SUMBER LAIN}

Akib, H. (2016). Implementasi Kebijakan Program Makassar Tidak Rantasa (MTR) di Kota Makassar. Jurnal Ilmiah Ilmu Administrasi Publik, 6(2), 21-34.

Diantha, I M P. (2016). Metodologi Penelitian Hukum Normatif Dalam Justifikasi Teori Hukum. Jakarta: Prenada Media Group.

Sumber WHO tanggal 02-08-2021 